Journal of Economic Theory 6(2): 48-60, 2012

ISSN: 1994-8212

(C) Medwell Journals, 2012

\title{
Macroeconomic Distortions and Stock Market Performance: Evidence from Nigeria
}

\author{
Adegoke I. Adeleke \\ Department of Economics, Osun State University, Osogbo, Nigeria
}

\begin{abstract}
This study investigates the extent to which various economic distortions have impacted on the stock market performance in Nigeria. This study employs Vector Error Correction Model (VECM) that is based on estimation of both short run and long run dynamics in the endogenous model. From the analysis conducted, the results suggest that distortions in economic variables have significant effects on the stock market performance in Nigeria. Specifically, it suggests that shocks in money supply have stronger impact on the stock market performance in Nigeria.
\end{abstract}

Key words: Vector Error Correction Model, economic variables, money supply, stock market, Endogenous Model, Nigeria

\section{INTRODUCTION}

The idea that financial market and economic activities may be interrelated phenomena is not new. It is easily traceable to the time of the great depression when the collapse of the financial system along with real economic activity struck the attention of economists (Gertler, 1988). Since then, economic literature has identified various ways in which stock market and the macroeconomy have been related. One way of considering the effects of macroeconomic factors on the stock prices is through the asset-pricing perspective in which Arbitrage Pricing Theory (APT) developed by Ross (1976) has been used as a framework to address the question of whether risk associated with particular macro variables is reflected in the expected stock returns. A closely-related analysis is that of the consumption-CAPM (Capital Asset Pricing Model) which concentrates on a single macro influence, the growth of aggregate consumption. An alternative to this direction of influence from the economy to the stock market is to analyze the effects of stock prices on the macroeconomy. A relationship of this nature is between stock prices and investment (in the case of capital formation). Studies of this type start with Tobin (1969)'s q-Theory of investment. The question literature in this area addresses is whether firms in making investment decisions should pay any heed to stock prices or whether stock prices are simply a veil over the real part of the economy which can be dispensed with when making decisions about real variables such as investment. The recent global financial turmoil has highlighted the importance of understanding the linkages between stock price changes and the real economy, both domestically and globally. At the domestic level, stock price changes affect wealth, confidence and the cost of capital which affect consumption and investment. Meanwhile, the global transmission of stock price shocks can have an impact on the real economy even in remote countries. Therefore, both macroeconomists and financial economists around the world are giving increasing attention to the relationship between the stock market and the rest of the economy (Black et al., 2001).

Many previous empirical studies in Nigeria (Soyode, 1993; Emenuga, 1994, 1996) have attempted to understand this relationship. They however found little or relatively insignificant relationship and in fact conflicting results between economic variables and stock market performance. These conflicting results have been traced to methodological challenges associated with the estimation methods such as single equation (OLS), the Engle-Granger two step procedures and the standard VAR Model, the use of which has dominated the empirical literature 2. Recent econometric techniques have shown the strong limitations to these techniques and revealed that most economic and stock market data have to be subjected to more rigorous analyses involving both the short- and long-run co-movement among a number of time series to achieve unbiased, consistent and efficient estimates (Johansen, 1991; Enders, 1995).

Therefore, this study addresses questions such as: can the dismal performance of the stock market be explained by the various distortions in the economy? What are the relationship between sharp swing in the liquidity and the stock market performance in Nigeria? In this regards, the recently purported simultaneous fall of the stock market prices and downturn in economic performance in Nigeria need to be addressed empirically. Essentially, this studyss analyses the relationship between economic distortions and stock market performance in Nigeria using a new methodological approach. It also expects to identify different transmission channels through which the distortions in fundamental 
economic variables get transmitted to stock market in Nigeria. Research which enhances a better and deeper understanding of this interrelationship will therefore, play an invaluable role in ensuring coherence and mutually reinforcing measures that not only promote the development of capital market in Nigeria but also ensure macroeconomic stability in the context of sustainable growth.

\section{Background of the study}

The stock market performance in Nigeria: The performance of any stock market is traditionally assessed based on some standardized indicators, some of which are: market capitalization, turnover, value and volume of traded shares, size (value) and number of primary market issues, new securities being listed on the exchange, among others. Following the existing literature, these highlighted yardsticks will be utilized to assess the performance of the Nigerian stock market for the period under review. Thus, the operational highlights and performance of the Nigerian Stock Market from 1995-2009 are shown in Table 1, using the key indicators.

Table 1 shows that there was some level of growth in the various market indicators for the period under review. The value of shares traded increased from 1.8 billion Naira (US\$13.85 million) in 1995 to 28.2 billion Naira (US\$0.22 billion) in 2000 and this has grown drastically to 2.4 trillion Naira (US\$18.5 billion) in 2008 . The volume of shares traded during the same period also increased from 0.397 billion in 1995 to 5 billion in 2000 and it has increased drastically to 193.1 billion in 2008. This represents a whopping growth rate of $3,762 \%$ between 2000 and 2008. Market capitalization as another important market indicator, also increased from 171.1 billion Naira
(US\$1.3 billion) in 1995 to 472.9 billion Naira (US $\$ 3.64$ billion) in 2000 and reached the peak in 2007 with 10.18 trillion Naira (US\$78.3 billion). It however declined to 6.958 trillion Naira (US\$53.7 billion) inyear, 2008. While the value for new issues fluctuated at the early part of the period, it however started increasing from year, 2000 to the end of financial year, 2005 and later declined to 650 million Naira in year, 2007. New issues as a proportion of GDP (Gross Domestic Product) at current market prices was also fluctuating at the beginning of the period under review when it declines from $0.052 \%$ in 1996 to $0.042 \%$ in 1998 and later started increasing persistently from $0.05 \%$ in 2000 to $0.501 \%$ in 2005 . This ratio however, drastically declined to $0.072 \%$ in year, 2007 . The importance of this (New issue/GDP) ratio is that it represents the size of funds mobilized by the stock market in relation to the GDP.

However, the growth in many stock market indicators was dampened around November, 2007 and this is obvious from the graphical representation of monthly NSE all-share index as shown in Fig. 1. Figure 1 shows that NSE all-share index increased gradually between 1985 to early 1997 when the market witnessed some forms of corrections. The market thereafter rose significantly and also witnessed another market downturn around mid 2004 to late 2006. There was however an unprecedented increase in the NSE All-share from late 2006 till around February, 2008 but the bearish situation has since taken over the market with the index plummeted drastically from February, 2008 to December, 2009. The market crashed as a result of many economic distortions such as liquidity and confidence erosion occasioned by the bust of the market following the aftermath of market manipulation through margin trading and capital withdrawal by foreign investors.

Table 1: Operational statistics and the Nigerian stock market performance (1995-2009)

\begin{tabular}{|c|c|c|c|c|c|c|c|}
\hline Years & $\begin{array}{l}\text { Value traded } \\
\text { (billion shares) }\end{array}$ & $\begin{array}{l}\text { Value traded } \\
\text { (N'billion) }\end{array}$ & $\begin{array}{c}\text { Market capitalization } \\
\text { (A'billion) }\end{array}$ & $\begin{array}{l}\text { The NSE } \\
\text { all share index }\end{array}$ & $\begin{array}{l}\text { New issues } \\
\text { (N'billion) }\end{array}$ & $\begin{array}{c}\text { No. of } \\
\text { listed companies }\end{array}$ & $\begin{array}{c}\text { New } \\
\text { issues/GDP (\%) }\end{array}$ \\
\hline 1995 & 0.40 & 1.84 & 171.10 & 5092.15 & 21.95 & 181.00 & 0.07 \\
\hline 1996 & 0.88 & 7.06 & 285.60 & 6890.90 & 21.45 & 183.00 & 0.05 \\
\hline 1997 & 1.30 & 11.07 & 282.00 & 6400.40 & 9.11 & 182.00 & 0.02 \\
\hline 1998 & 2.10 & 13.57 & 263.30 & 5690.96 & 17.28 & 186.00 & 0.04 \\
\hline 1999 & 3.95 & 14.08 & 300.06 & 5179.17 & 44.44 & 196.00 & 0.09 \\
\hline 2000 & 5.00 & 28.15 & 472.90 & 8111.01 & 35.50 & 195.00 & 0.01 \\
\hline 2001 & 5.90 & 57.60 & 662.60 & 10963.43 & 44.17 & 194.00 & 0.06 \\
\hline 2002 & 6.60 & 60.30 & 763.90 & 12137.72 & 67.32 & 195.00 & 0.08 \\
\hline 2003 & 13.30 & 120.70 & 1350.00 & 20128.94 & 164.84 & 200.00 & 0.16 \\
\hline 2004 & 19.21 & 225.82 & 2112.00 & 23844.45 & 235.53 & 207.00 & 0.20 \\
\hline 2005 & 26.70 & 262.94 & 2900.00 & 24085.76 & 730.54 & 214.00 & 0.50 \\
\hline 2006 & 36.70 & 470.25 & 4227.10 & 33189.30 & 690.00 & 202.00 & 0.37 \\
\hline 2007 & 138.10 & 2100.00 & 10180.30 & 57990.22 & 650.00 & 212.00 & 0.07 \\
\hline 2008 & 193.10 & 2400.00 & 9560.00 & 31450.78 & 2600.00 & 213.00 & 0.27 \\
\hline 2009 & 102.85 & 685.72 & 7030.00 & 20827.17 & 279.25 & 216.00 & 0.03 \\
\hline
\end{tabular}

Nigerian Stock Exchange (NSE), Annual Reports (various issues) and NSE Factbook (various issues); Researchers use exchange rate of $\$ 1=130$ in the previous discussions 


\section{J. Econ. Theroy, 6(2): 48-60, 2012}

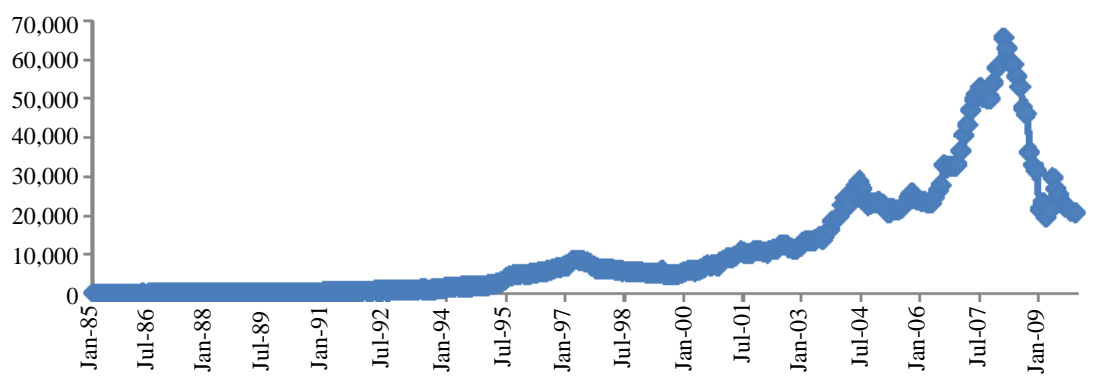

Fig. 1: NSE all-share index (Jan. 1985 to Dec. 2009) (CBN statistical bulletin (2008) and NSE weekly report)

Nigerian economic environment and the stock market: The importance of stock markets in any modern economy can be appreciated by understanding the multiple functions that the stock markets perform. Traditionally, stock exchanges are required to perform two basic roles in any economy. One is that of the price discovery and second is that of providing liquidity. They provide a fillip to the primary issues market and make it possible for corporate bodies and government to undertake huge investments. The liquidity aspect provides incentive to the ultimate savers in the economy so that a well regulated and efficient stock market does indeed serve as a useful conduit for linking savers (surplus units) to ultimate borrowers (deficit unit), usually corporate bodies and government.

In particular in an environment characterized by uncertainty, stock markets provide functions beyond capital or savings mobilisation. They also facilitate other functions such as risk allocation and risk sharing among market participants. That is stock market is expected to provide opportunities for risk diversification, allocation and help channel risky assets to the best valued use. Risk sharing in turn allows high risk, yet high returns, projects to be undertaken; otherwise such projects would be rationed out of the economy, leading to adestruction of value for the economy. Value destruction eventually aggregates into poor performance. Moreover, stock markets can serve as a vital governance function in disciplining management in an environment with imperfect information and incentive problems. These problems are likely to prevail among various stakeholders to an organised enterprise: management, shareholders, creditors, employees, suppliers, customers, government, etc. In addition, market determined stock prices and yields provide a benchmark against which the cost of capital for and returns on investment projects can be judged, even if such projects are not in fact financed through the stock markets. As stock markets are forward looking, they also provide a unique record of the shifts in investors' views about the future prospects of companies as well as the economy in general. In many respects, therefore a capital market is a vast information exchange which efficiently reduces transaction costs and thus enhances the economy as a whole (Green et al., 2000). The main argument is that as much as the stock market is important for the economy as a whole, the benefits of economic growth also have an important impact on the stock market performance and that any distortions in the economy can also have effects on the stock market.

In Nigeria, several economic distortions have been experienced, some of which are perceived as having strong link with the stock market operations. Some obvious economic distortions include the sharp swing in the liquidity, high interest rates spread, exchange rate fluctuations, inflation spiral, low capacity utilisation, unstable economic growth rates and political instability among other factors which has resulted in thinness of trading, low market capitalization, low turnover, low and/or negative performance ratios.

The sharp swing in the liquidity, from an abundance of liquidity (that is associated with the period of boom in the stock market) to the acute shortage of liquidity (which also resulted into the bust in the market) is one of the major economic distortions that have been experienced in the recent years. One of the factors underlying these swings has been the dependence of the financial system on the injection of liquidity from outside, even as the natural growth of financial savings has remained stunted. Another factor directly influencing the swings in liquidity in Nigeria is the recent pronouncement by the Central Bank of Nigeria (CBN) about the high non-performing loans in the portfolios of banks in Nigeria and thus, raising issues relating to corporate governance. This led to the $\mathrm{CBN}$ removing the management boards of some nine banks in Nigeria and injection of N200 billion, fresh liquidity into those banks. This period also witnessed CBN having to guarantee interbank loans. Also, the indirect policy of discouraging banks for lending for investors in the stock market is another factor that may hinder the performance of stock market in Nigeria. The apparent consequence of swings in liquidity is seen in increased uncertainty for both the purveyors of 
institutional credits and productive enterprises seeking credit. Another form of distortions can be seen in the structure of interest rates. While the short term rates for savings are going down, the rates for bank loans and loans for term lending remained high and sticky as a result of the high cost funds mobilised by banks. The high returns previous experienced in the stock market has wet the appetite of savers, thus making them requiring higher interest rate on saving that is hardly generated from other form of investment. As can be seen from Fig. 2 which analyse the trend of market capitalisation and domestic credit to the economy. The graph indicates that crash (raise) in the credit market precedes the fall (boom) in the stock market capitalisation. In other words, the volume of liquidity in the economy has a positive relationship with the performance of the stock market. This signifies co movement of the liquidity level and the stock market. Figure 3 shows that the relationship between stock market indicator and some economic variables is not a straight forward one and that empirical investigation would be needed to ascertain the exact relationship. The only variable that seems have unambiguous relationship with stock market is interest rate.
From Fig. 3, researchers can observe that the stock market measure rises (falls) when the interest rate falls (rises). That is interest rate is expected to have inverse relationship with stock market measure a-priori. Subsequent to the deregulation of interest rate in the post $\mathrm{SAP}$ era, the spread between deposit and lending rates begin to widen and thus, interest rates increased remarkably. The high interest rate implies that costs of borrowing have gone up in the organised financial market, thereby increasing the cost of operations. However, a measure of distortions in the money market is the increasing divergence between the lending rate and the deposit rate otherwise known as the interest rate spread. The spread rose from $-0.25 \%$ in 1985 to 13.7 in 1992 and a height of $20.7 \%$ in 2002. This spread has since been on the high side. The impact of these distortions in the money market hinders efficiency and competitiveness of the financial sector and stock market in particular with consequent negative impact on the real sector of the economy.

Literature review: Although, a lot of studies relating economic factors to stock market performance have been

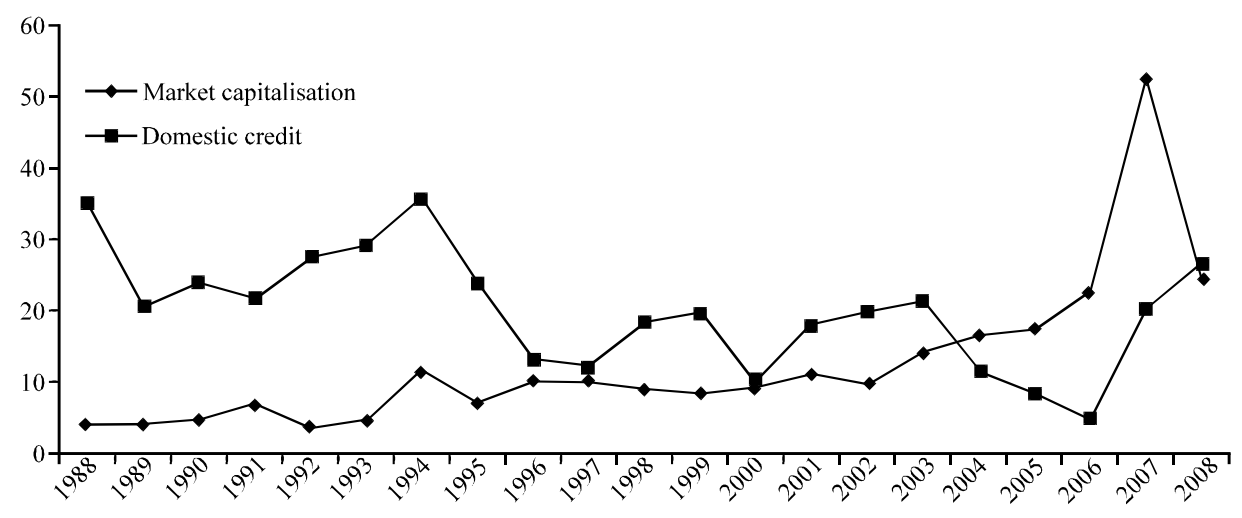

Fig. 2: Trend of market capitalisation and domestic credit to the private sector (Billion) (Central Bank of Nigeria (CBN) Statistical Bulletin, 2008)

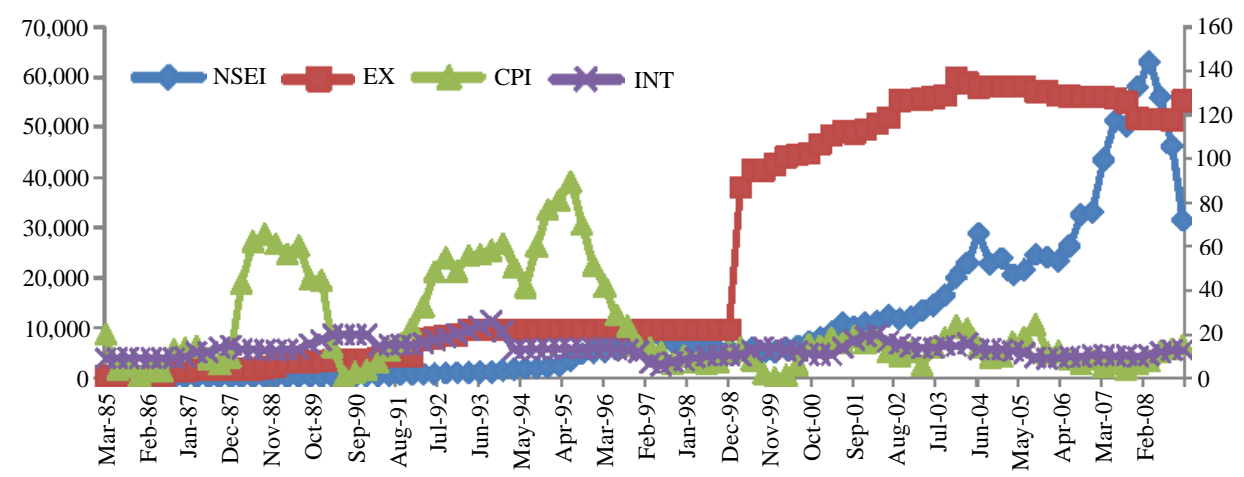

Fig. 3: Trend analysis of exchange rate, inflation rate, interest rate and NSE index (March 1985 to Dec. 2008) 


\section{J. Econ. Theroy, 6 (2): 48-60, 2012}

conducted in both the developed and emerging markets, however the major focus in this study will be on the studies carried out on African markets where relatively few studies have been carried out on this important issue. Doing this will assist us to concentrate on relevant studies that have directly address the study area. It will also help in identifying the important economic variables that may bring about distortions and thus have been empirically verified to have impact on the stock market. The first known empirical study in this area was carried out by Chen et al. (1986). They hypothesized and tested a set of macroeconomic data series to explain US stock returns. They investigated the sensitivity of macroeconomic variables to stock returns using seven macroeconomic variables namely: industrial production, inflation, term structure of interest rate, consumption, market indices and oil prices. They found a strong relationship between the macroeconomic variables and the expected stock returns. They noted that industrial production, changes in risk premium, twist in the yield curve and measured unanticipated inflation and changes in expected inflation during period when these variables are highly volatile are significant in explaining expected returns. Their evidence suggested that consumption, oil prices and market index are not priced by the financial market. They concluded that stock returns are exposed to systematic news that is priced by the market.

Chen performed the second study covering the USA by including other macro variables such as dividend-price ratio, default spread, etc. $\mathrm{He}$ found out that future stockmarket returns could be forecasted by interpreting some macroeconomic variables such as default spread, term spread, 1 month T-bill rate, industrial production growth rate and the dividend-price ratio.

In the UK, Poon and Taylor (1991) suggested that the model used for testing the APT cannot be used for making prediction in UK stock market. This means that the share prices in the UK market are not affected in a similar manner to that reported in Chen et al. (1986). This can be explained by the idea that other explanatory variable may be at work in UK or the Chen methodology is inadequate. They concluded that there is no conclusive result that can be made regarding the applicability of the APT to the capital market of the UK. However, Clare and Thomas (1994) investigated the effect of eighteen macroeconomic factors on stock returns in the UK. They found oil prices, retail price index, bank lending and corporate default risk to be important risk factors for the UK stock returns.

Priestley pre-specified the factors that may carry a risk premium in the UK stock market. Seven macroeconomic and financial factors; namely default risk, industrial production, exchange rate, retail sales, money supply, unexpected inflation, change in expected inflation, terms structure of interest rates, commodity prices and market portfolio are found to be significant. For the APT Model with the factor generating from the rate of change approach all factors are found to be significant.

A study by Flannery and Protopapadakis (2002) reassessed the effect of some macro announcement series on US stock returns using the GARCH Model. Six macroeconomic variables, namely; balance of trade, housing starts, employment, consumer price index, Money supply (M1) and producer price index seem to affect stock returns. On the other hand, two popular measures of aggregate economic activity (real GNP and industrial production) do not appear to be related with stock returns. Kandir (2008) investigated the role of macroeconomic factors in explaining Turkish stock returns using Macroeconomic Factors Model and seven macroeconomic variables (growth rate of industrial production index, change in consumer price index, growth rate of narrowly defined Money supply (M1), change in exchange rate, interest rate, growth rate of international crude oil price and return on the MSCI World Equity Index). The study found out that exchange rate, interest rate and world market return seem to affect all of the portfolio returns while inflation rate is significant for only three of the twelve portfolios. Industrial production, money supply and oil prices do not appear to have any significant effect on stock returns.

In Nigeria, the available literature revealed that Soyode (1993) was the first to test the relationship between stock prices and macroeconomic variables (exchange rate, inflation and interest rates) in Nigeria. He observed that these macroeconomic variables are statistically associated with the aggregate stock price. Therefore, the study concluded that macroeconomic variables significantly explained stock market behaviour in Nigeria during the period. However, the study did not show whether these macroeconomic variables have long run relationship with stock prices. Emenuga $(1994,1996)$ examined the role of macroeconomic variables in estimating stock prices.

Both studies, however found that all the macroeconomic factors (exchange rate, interest rate, money supply, change in rate of inflation, expected rate of inflation and the unexpected rate of inflation) are not significantly different from zero. That is none of the economic variables is important in explaining stock market performance in Nigeria. He, therefore used the weak regulatory process during the period to explain the poor sensitivity of equity prices to these macroeconomic variables. Nwokoma improved on the previous studies in Nigeria by conducting unit root and cointegration tests. The study used the methodology of VAR to examine the relationship between macroeconomic variables and stock market performance from 1988-2002. The results from the study shows that only industrial production and the level 


\section{J. Econ. Theroy, 6 (2): 48-60, 2012}

of interest rates, as represented by the 3 months commercial deposit rate appear to have long run relationship with the stock market. The study concludes that stock prices in the Nigera stock market responds more to its past prices than to changes in the macroeconomic variables.

For other African countries, Tsuyoshi (1997) studied the sources of monthly return variation in the Zimbabwean stock market. The study used the Principal Component Analysis (PCA) to analysis the data. The results indicate that stock returns were significantly correlated with the macroeconomic variables like money supply, short-term interest rates, commodity prices and exchange rate.

The selected macroeconomic variables were able to explain an average of $40 \%$ of the return variation in this market. In South Africa, Jefferis et al. (2001) reported that the real stock market index of the Johannesburg Stock Exchange (JSE) has a positive long-term relationship with real GDP and real exchange rate and a negative relationship with real long-term interest rate over the period 1985-1995.

Osei (2002) investigated the long run and short run relationship between Ghana stock market and some selected macroeconomic variable (money supply, inflation, exchange rate and gold price) using cointegration techniques. The research reported long run relationship between the selected macroeconomic variables and Ghana stock market.

\section{MATERIALS AND METHODS}

A widely used theoretical framework in this kind of study is the Arbitrage Pricing Theory (APT) developed by Ross (1976) and enhanced by others. APT is based on the law of one price which states that two otherwise identical assets cannot sell at different prices. It assumes that asset returns are linearly related to a set of indexes, each representing a factor that influences the return of an asset. Asset returns are randomly generated according to an n-factor model:

$$
\mathrm{R}_{\mathrm{i}}=\mathrm{E}\left(\mathrm{R}_{\mathrm{i}}\right)+\beta_{\mathrm{i} 1} \delta_{1}+\beta_{\mathrm{i} 2} \delta_{2}+\ldots \beta_{\mathrm{in}} \delta_{\mathrm{n}}+\mathrm{e}_{\mathrm{i}}
$$

Where:

$\mathrm{R}_{\mathrm{i}}=$ The actual (random) rate of return on asset $\mathrm{i}$ in any given period

$E\left(R_{i}\right)=$ The expected return on asset $i$

$\delta_{\mathrm{n}}=\mathrm{A}$ common factor with a zero mean that influences the returns on all assets

$\beta_{\text {in }} \quad=$ Sensitivity of asset $\mathrm{i}$ to factor $\mathrm{n}$

$\mathrm{e}_{\mathrm{i}}=$ Random error term, unique to asset $\mathrm{i}$
The sensitivity measure in APT has similar interpretations as in Capital Asset Pricing Model (CAPM). They are measures of the relative sensitivity of an asset's return to a particular risk factor. Considering the risk premia in both cases, the CAPM relationship would be the same as would be provided by APT if there were only one pervasive factor influencing returns. The main consequence of the APT is a pricing equation that looks like a multifactor version of the CAPM equation. In conjunction with the assumption of zero arbitrage profits, the above multiple factor models lead to the APT pricing equation:

$$
\mathrm{E}\left(\mathrm{R}_{\mathrm{i}}\right)=\lambda_{\mathrm{o}}+\beta_{\mathrm{i} 1} \lambda_{1}+\beta_{\mathrm{i} 2} \lambda_{2}+\ldots \beta_{\mathrm{in}} \lambda_{\mathrm{n}}+\eta_{\mathrm{i}}
$$

where, $\lambda_{\mathrm{n}}$ are interpreted as risk premium (if there is a risk-free rate then $\lambda_{0}=\lambda_{\mathrm{f}}$ ). The APT literature suggests that macroeconomic variables may proxy for pervasive risk factors and that multiple risk factors can explain asset returns (Burmeister and McElroy, 1988).

The empirical study of APT, carried out by Roll and Ross (1980) maintained that the factors derived in the APT framework should be fundamental economic aggregates, such as GNP (Gross National Products), interest rate, exchange rate, etc. and therefore suggested investigation of economic factors that are proxied by derived factors in the APT. Chen et al. (1986), henceforth refer to as CRR is the first to employ specific economic factors as proxies for undefined variables in the APT. The CRR attempted to express the equity returns as a function of macroeconomic variables. This is an improvement on the initial APT framework and it is referred to as Macroeconomic Factors Model (MFM). The basic idea here is that since economic forces influence expected dividends and the discount rate, it can be concluded that stock prices and hence, stock returns are systematically affected by economic variables. The discount rate is expected to change with the level of interest rates, Arbitrage profits can be described as the practice of taking advantage of a state of imbalance between two (or possibly more) markets and thereby making a risk-free profit term structure and risk premium. Expected dividends may change because of inflation rate, real production, oil prices and consumption. Drawing inspirations from the theoretical framework, the empirical model can be specified as:

$$
\Delta \mathrm{X}_{\mathrm{t}}=\mu+\sum_{\mathrm{i}=1}^{\mathrm{k}-1} \Gamma_{\mathrm{i}} \nabla \mathrm{X}_{\mathrm{t}-1}+\Pi \mathrm{X}_{\mathrm{t}-\mathrm{k}}+\epsilon_{\mathrm{t}}
$$

where, $\epsilon_{\mathrm{t}}$ is $\mathrm{p} \mathrm{x} 1$ vector of white noise error terms. The terms $\sum_{\mathrm{i}=1}^{k-1} \Gamma_{\mathrm{i}} \nabla \mathrm{x}_{\mathrm{t}-1}$ and $\Pi \mathrm{x}_{\mathrm{t}-\mathrm{k}}$ the Vector Autoregressive 


\section{J. Econ. Theroy, 6 (2): 48-60, 2012}

(VAR) component in the first differences and errorcorrection components, respectively. $\mathrm{X}_{\mathrm{t}}$ includes all macroeconomic variables, is a p x 1 vector and is integrated of order one. $\mu$ is a $\mathrm{p} \times 1$ vector of constants. $\mathrm{k}$ is a lag structure. The parameter $\Gamma_{\mathrm{i}}$ is a $\mathrm{px} \mathrm{p}$ matrix that represents short term adjustments among variables across $\mathrm{p}$ equations at the ith lag. $\Pi$ denotes a $\mathrm{px}$ p matrix that contains the information about the rank and hence, the long term relationship among the variables. Therefore, the above model specification will be carried out using the Vector Error Correction Model (VECM) that allows for the co-existence of both short and long run forces that drive the often ignored deviating and cyclical influences so inherently interactive with these aggregate variables over such a time horizon. The estimation of the cointegration also takes into consideration the issue of spurious regression. Researchers would conduct the Impulse Response Functions (IRF) and Variance Decomposition (VD) based on a VECM specification to address the transmission mechanism issue.

The study makes use of quarterly time series data from January, 1985 to December, 2009. Data used in this study consist of All-share Index Return (ASIR) of the Nigerian stock exchange, US Dollar exchange rate expressed as the amount of Nigerian Naira per unit of US Dollar (EXRN), Treasury Bill Rate (TBR), Nigerian Consumers' Price Index (CPI), Broad Money supply (M2), Gross Domestic Product (GDP), Credit to the Private Sector (CPS) and International Crude Oil prices (OP). Data on the macroeconomic variables are sourced from various issues of the Central Bank of Nigeria Statistical Bulletin and quarterly reports as well. This study makes use of a relatively longer time series data than any previous studies examining this relationship in Nigeria as the IMF International Financial Statistics CD-ROM while the stock exchange performance variables are sourced from the Nigerian Stock Exchange (NSE).

\section{RESULTS AND DISCUSSION}

Unit root test: A necessary but not sufficient condition for cointegration and VECM is that all series should share the same integrational properties in a univariate sense. Prior to testing for cointegration, researchers investigated the integrational properties of each of the variables by applying unit-root testing procedure. This study makes use of Philips-Perron (PP) tests. The result shows that all variables are not stationary in levels. After first difference, the PP test of unit root indicates that all variables employed are stationary at $1 \%$ level and their use would not lead to spurious regression. Therefore, all the series are stationary or integrated of the same order one that is I(1) as expected (Table 2).
Table 2: Results of unit root tests using Phillips-Perron (PP) Tests

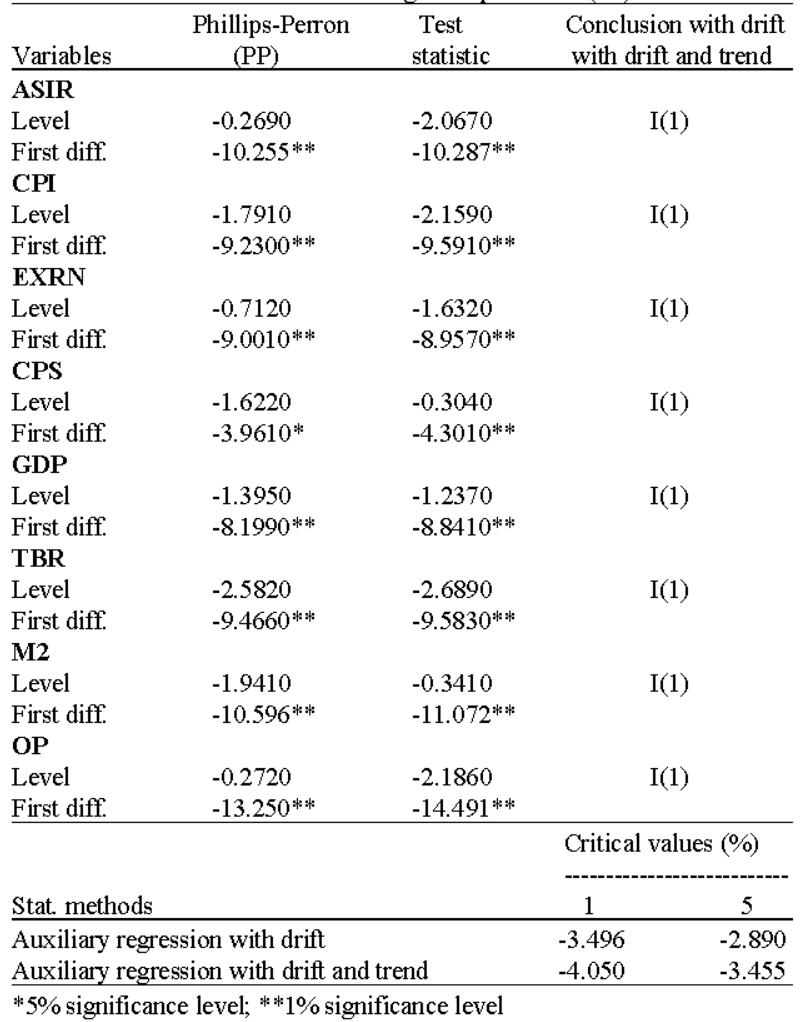

Table 3: Multivariate Johansen Cointegration Test results based on Maxeigen value statistics

Hypothesized No.

\begin{tabular}{|c|c|c|c|c|c|}
\hline \multicolumn{2}{|c|}{ of $\mathrm{CE}(\mathrm{s})$} & \multirow{2}{*}{$\begin{array}{l}\text { Eigen } \\
\text { value }\end{array}$} & \multirow{2}{*}{$\begin{array}{l}\text { Max-eigen } \\
\text { value } \\
\text { statistics }\end{array}$} & \multicolumn{2}{|c|}{ Critical values (\%) } \\
\hline Null & Altemative & & & 5 & 1 \\
\hline$r=0$ & $\mathrm{r}=1^{\text {*** }}$ & 0.452 & 60.123 & 51.42 & 57.69 \\
\hline$r \leq 1$ & $r=2$ & 0.371 & 46.418 & 45.28 & 51.57 \\
\hline$r \leq 2$ & $r=3$ & 0.324 & 39.115 & 39.37 & 45.10 \\
\hline$r \leq 3$ & $r=4$ & 0.267 & 31.032 & 33.37 & 38.77 \\
\hline$r \leq 4$ & $r=5$ & 0.209 & 23.463 & 27.07 & 32.24 \\
\hline$r \leq 5$ & $r=6$ & 0.167 & 18.281 & 20.97 & 25.52 \\
\hline$r \leq 6$ & $r=7$ & 0.138 & 14.879 & 14.07 & 18.63 \\
\hline $\mathrm{r} \leq 7$ & $r=8$ & 0.046 & 4.740 & 3.76 & 6.65 \\
\hline
\end{tabular}

All the variables are cointegrated at $1 \%$ level; the test allows for a linear deterministic trend in the data; trace statistics indicates one cointegrating equation(s) at $1 \%$ level; $r$ represents the number of cointegrating vectors. Maximum lag is $2 ;{ }^{*}\left({ }^{* *}\right)$ denotes rejection of the hypothesis at the $5 \%(1 \%)$ level, respectively. The asymptotic critical values are from Osterwald-Lenum

Cointegration test: Having established that the variables are integrated of the same order, we proceed to testing for cointegration. The Johansen and Juselius (1990) maximum likelihood procedure was applied in determining the cointegrating rank of the system and the number of common stochastic trends driving the entire system. Researchers reported the maximum eigen value statistics and its critical values at both 1 and $5 \%$ in Table 3 . The result of Multivariate Cointegration Test based on Johansen and Juselius (1990) Cointegration Technique reveal that there is one cointegrating relationship between 
the stock market returns and the economic variables at either the 1 or $5 \%$ significant level. These results suggest that the appropriate model to use is the VECM specification with one cointegrating vector in the model.

Vector Error Correction Model: Researchers proceed to estimate the VECM that is designed for use with non-stationary series that are known to be cointegrated. The VECM has cointegration relations built into the specification so that it restricts the long run behaviour of the endogenous variables to converge to their cointegrating relationship while allowing for short-run adjustment dynamics.

The cointegration term is known as the Error Correction Term (ECT), since the deviation from long-run equilibrium is corrected gradually through a series of partial short-run adjustments. The results are shown in Table 4. It shows that some macroeconomic variables are crucial in influencing the performance of the stock market as only few of the test statistics are significant. The results were evaluated using the conventional diagnostic tests. The estimated VECM satisfy the stability condition that is the vector error correction term in each of the models should have the required negative sign and lie within the accepted region of less than unity.

From the empirical results, researchers observe insignificant negative relationship between distortions in inflation pattern and the stock returns. Although, it has the right sign from the a-priori expectation but it is insignificant in the estimation.

Therefore, a $1.0 \%$ rise in inflation induces about $0.49 \%$ rise in stock market returns. This study is in conformity with the studies by Fama and Schwert (1977), Chen et al. (1986) and Mukherjee and Naka (1995) which also found negative relationship between stock returns and inflation.

Table 4: Results of the Estimated Vector Error Correction Model

\begin{tabular}{|c|c|c|c|c|c|c|c|c|}
\hline & \multicolumn{8}{|c|}{ System equations } \\
\hline & D(ASIR) & $\mathrm{D}(\mathrm{CPI})$ & $\mathrm{D}(\mathrm{EXRN})$ & $\mathrm{D}(\mathrm{CPS})$ & D(GDP) & $\mathrm{D}(\mathrm{TBR})$ & $\mathrm{D}(\mathrm{M} 2)$ & $\mathrm{D}(\mathrm{OP})$ \\
\hline \multirow[t]{2}{*}{ ECT } & -0.233 & -0.079 & -0.035 & -0.070 & -0.023 & -0.063 & -0.219 & -0.067 \\
\hline & {$[-4.132]^{* * *}$} & {$[-2.473]^{*}$} & {$[-0.231]$} & {$[-1.397]$} & {$[-0.745]$} & {$[-0.672]$} & {$[-4.568]^{* * *}$} & {$[-0.698]$} \\
\hline \multirow[t]{2}{*}{ D(ASIR(-1)) } & 0.404 & -0.134 & -0.266 & 0.074 & 0.047 & 0.069 & -0.276 & 0.322 \\
\hline & {$[4.038]^{* * *}$} & {$[-2.372]^{*}$} & {$[-1.001]$} & {$[0.834]$} & {$[0.843]$} & [0.414] & {$[-3.248]^{* * *}$} & {$[1.893]^{*}$} \\
\hline \multirow[t]{2}{*}{ D(ASIR(-2)) } & 0.185 & -0.110 & -0.233 & -0.058 & 0.051 & -0.258 & -0.174 & 0.195 \\
\hline & {$[1.838]^{*}$} & {$[-1.935]^{*}$} & {$[-0.871]$} & {$[-0.653]$} & {$[0.901]$} & {$[-1.544]$} & {$[-2.031]^{*}$} & [1.144] \\
\hline \multirow[t]{2}{*}{$\mathrm{D}(\mathrm{CPI}(-1))$} & -0.490 & -0.247 & 0.047 & -0.660 & -0.076 & -0.452 & 0.073 & -0.142 \\
\hline & {$[-2.931]^{* * *}$} & {$[-2.622]^{*}$} & {$[0.105]$} & {$[-4.447]^{* * *}$} & {$[-0.809]$} & {$[-1.622]$} & {$[0.516]$} & {$[-0.500]$} \\
\hline \multirow[t]{2}{*}{$\mathrm{D}(\mathrm{CPI}(-2))$} & -0.154 & -0.245 & -0.357 & -0.175 & -0.058 & -0.306 & 0.211 & 0.043 \\
\hline & {$[-0.888]$} & {$[-2.515]^{*}$} & {$[-0.777]$} & {$[-1.140]$} & {$[-0.603]$} & {$[-1.061]$} & [1.431] & {$[0.148]$} \\
\hline \multirow[t]{2}{*}{$\mathrm{D}(\operatorname{EXRN}(-1))$} & -0.091 & 0.016 & -0.586 & -0.001 & 0.023 & 0.066 & 0.058 & 0.048 \\
\hline & {$[-2.124]^{*}$} & [0.659] & {$[-5.166]^{* * *}$} & {$[-0.038]$} & [0.969] & {$[0.927]$} & [1.588] & {$[0.662]$} \\
\hline \multirow[t]{2}{*}{$\mathrm{D}(\operatorname{EXRN}(-2))$} & 0.011 & -0.003 & -0.325 & -0.007 & 0.024 & -0.071 & -0.002 & 0.074 \\
\hline & {$[0.250]$} & {$[-0.136]$} & {$[-2.905]^{* * *}$} & {$[-0.180]$} & [1.021] & {$[-1.004]$} & {$[-0.042]$} & {$[1.037]$} \\
\hline \multirow[t]{2}{*}{$\mathrm{D}(\mathrm{CPS}(-1))$} & 0.020 & 0.129 & 0.073 & -0.537 & -0.107 & 0.495 & -0.142 & 0.101 \\
\hline & {$[0.166]$} & {$[1.850]^{*}$} & {$[0.223]$} & {$[-4.895]^{* * *}$} & {$[-1.541]$} & {$[2.408]^{*}$} & {$[-1.347]$} & {$[0.480]$} \\
\hline \multirow{2}{*}{$\mathrm{D}(\mathrm{CPS}(-2))$} & 0.112 & 0.240 & -0.258 & -0.084 & -0.048 & -0.282 & -0.164 & -0.058 \\
\hline & {$[0.875]$} & {$[3.320]^{* * *}$} & {$[-0.760]$} & {$[-0.743]$} & {$[-0.676]$} & {$[-1.323]$} & {$[-1.503]$} & {$[-0.267]$} \\
\hline \multirow[t]{2}{*}{$\mathrm{D}(\mathrm{GDP}(-1))$} & 0.278 & 0.165 & 0.331 & -0.041 & -0.274 & -0.284 & -0.431 & -0.265 \\
\hline & {$[1.207]$} & [1.266] & {$[0.540]$} & {$[-0.200]$} & {$[-2.120]^{*}$} & {$[-0.740]$} & {$[-2.194]^{*}$} & {$[-0.678]$} \\
\hline \multirow[t]{2}{*}{$\mathrm{D}(\mathrm{GDP}(-2))$} & 0.572 & 0.005 & -0.518 & -0.068 & 0.044 & -0.148 & 0.056 & -0.330 \\
\hline & {$[2.718]^{*}$} & [0.041] & {$[-0.926]$} & {$[-0.366]$} & {$[0.377]$} & {$[-0.423]$} & {$[0.310]$} & {$[-0.923]$} \\
\hline \multirow[t]{2}{*}{$\mathrm{D}(\mathrm{TBR}(-1))$} & -0.157 & -0.049 & 0.091 & -0.012 & 0.007 & -0.220 & -0.065 & 0.080 \\
\hline & {$[-2.280]^{*}$} & {$[-1.258]$} & {$[0.497]$} & {$[-0.201]$} & [0.191] & {$[-1.922]$} & [-1.113] & [0.688] \\
\hline \multirow[t]{2}{*}{$\mathrm{D}(\mathrm{TBR}(-2))$} & -0.028 & 0.043 & -0.003 & -0.138 & -0.022 & -0.008 & -0.195 & 0.054 \\
\hline & {$[-0.468]$} & [1.255] & {$[-0.016]$} & {$[-2.564] *$} & {$[-0.648]$} & {$[-0.080]$} & {$[-3.768]^{* * *}$} & {$[0.526]$} \\
\hline \multirow[t]{2}{*}{$\mathrm{D}(\mathrm{M} 2(-1))$} & -0.252 & 0.314 & -0.325 & -0.046 & -0.032 & -0.197 & -0.058 & 0.241 \\
\hline & {$[-1.488]$} & {$[3.285]^{* * *}$} & {$[-0.723]$} & {$[-0.308]$} & {$[-0.339]$} & {$[-0.698]$} & {$[-0.400]$} & {$[0.837]$} \\
\hline \multirow[t]{2}{*}{$\mathrm{D}(\mathrm{M} 2(-2))$} & -0.100 & 0.230 & 0.124 & 0.180 & -0.117 & 0.052 & 0.116 & -0.274 \\
\hline & {$[-0.768]$} & {$[3.118]^{* * *}$} & {$[0.357]$} & [1.546] & {$[-1.599]$} & {$[0.241]$} & [1.039] & {$[-1.231]$} \\
\hline \multirow[t]{2}{*}{$\mathrm{D}(\mathrm{OP}(-1))$} & 0.116 & 0.064 & -0.172 & -0.014 & -0.019 & 0.064 & 0.116 & -0.448 \\
\hline & {$[1.783]$} & [1.749] & {$[-0.998]$} & {$[-0.247]$} & {$[-0.511]$} & {$[0.590]$} & {$[2.093]^{*}$} & {$[-4.051]^{* * k}$} \\
\hline \multirow[t]{2}{*}{$\mathrm{D}(\mathrm{OP}(-2))$} & -0.008 & 0.037 & 0.020 & 0.026 & -0.032 & 0.013 & 0.029 & -0.350 \\
\hline & {$[-0.116]$} & {$[0.100]$} & [0.114] & {$[0.447]$} & {$[-0.861]$} & [0.116] & {$[0.512]$} & {$[-3.120]^{*+k}$} \\
\hline \multirow[t]{2}{*}{$\mathrm{C}$} & -0.001 & 0.000 & -0.001 & -0.001 & 0.000 & 0.000 & 0.000 & 0.000 \\
\hline & {$[-0.122]$} & {$[0.037]$} & {$[-0.041]$} & {$[-0.094]$} & {$[0.051]$} & [0.019] & {$[0.024]$} & {$[0.030]$} \\
\hline \multicolumn{9}{|c|}{ Summary statistics } \\
\hline $\mathrm{R}^{2}$ & 0.465 & 0.543 & 0.333 & 0.448 & 0.196 & 0.376 & 0.535 & 0.369 \\
\hline Adj. $R^{2}$ & 0.354 & 0.448 & 0.195 & 0.333 & 0.030 & 0.247 & 0.438 & 0.238 \\
\hline
\end{tabular}




\section{J. Econ. Theroy, 6 (2): 48-60, 2012}

The results of the study support the hypothesis of a positive relationship between credit to the private sector and the stock market return. A 1.0\% increase in the credit to private sector generates $0.02 \%$ increase in stock market returns. This shows that very small fractions of credit to the private sector are invested in the stock market in Nigeria. The negative relation between interest rate and stock returns is consistent with the a-priori expectation. The findings show that interest rates have significant negative relations with returns in the Nigerian's stock market. A $1.0 \%$ rise in interest rate stimulates $0.16 \%$ decline in stock market returns as investors would massively move their funds away from the stock market (which has higher risk) to money market (which has lower risk) as a result of increase in treasury bill rate (which represents riskless rate). Also, restrictive policies via higher interest rates or discount rates would make cash flows worthless after being discounted. This would reduce the attractiveness of investment, thereby shrinking the value of stock returns. From the substitution effect hypothesis, a rise in the rate of interest increases the opportunity cost of holding cash which later leads to a substitution effect between stocks and other interest bearing securities like bonds. Both the restrictive policy and the substitution effect hypothesis suggest that interest rate should be inversely related to stock market returns.

As interest rate is proxied by the treasury bill rate which serves as a better proxy for the nominal risk-free component used in the discount rate in the stock valuation models and may also serve as a surrogate for expected inflation in the discount rate.

This result is consistent with the findings of Bulmash and Trivoli in the case of the United States, Mukherjee and Naka (1995) for Japan, Maysami and Koh (2000) for Singapore and Rahman et al. (2009) for Malaysia. Similarly, the empirical results are in conformity with a
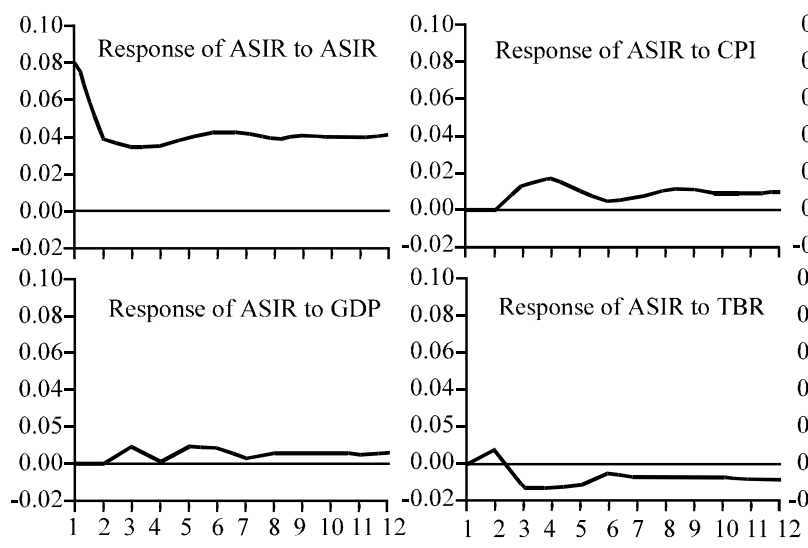

priori expectation of positive relationship between stock returns and economic activity. Researchers found that stock returns are positively and significantly related to the real economic activity as proxy by the gross domestic product at lag 2. A $1.0 \%$ rise in economic activity therefore induces around $0.57 \%$ increase in stock market returns as investors would interpret economic growth as favourable news in the stock market, thereby generating positive returns. This can be explained through the multiple effects of growing economic activity on companies expected future cash flows, changes in production level affect the employment level, spending and profitability of firms. These changes are reflected on the market value of assets. Therefore, market returns indicate a co-movement with the fluctuations in production level. A similar relation is found in the United States (Fama and Schwert, 1977; Chen et al., 1986; Mukherjee and Naka, 1995) for Japan.

Impulse response analysis: Researchers now examine the impulse response analysis of the system using Cholesky one standard deviation innovations. The Impulse Response Functions (IRF) trace the long-run responses of the system variables to one-standard deviation shocks to the system innovations spanning over the initial 12 quarters or 3 years. From IRF, it is possible to observe whether an impulse in a variable leads to a fall or rise in the other variable.

The impulse response graphs are shown in Fig. 4. The results show that each variable responds significantly to its own one-standard deviation shock. For instance, a one-standard deviation shock to innovations of ASIR causes it to jump above its equilibrium level instantaneously. Thereafter, NSEIR declines but still remains above its equilibrium level throughout the 12 quarter forecast horizon. In addressing the issue of how stock market respond to shocks in economic

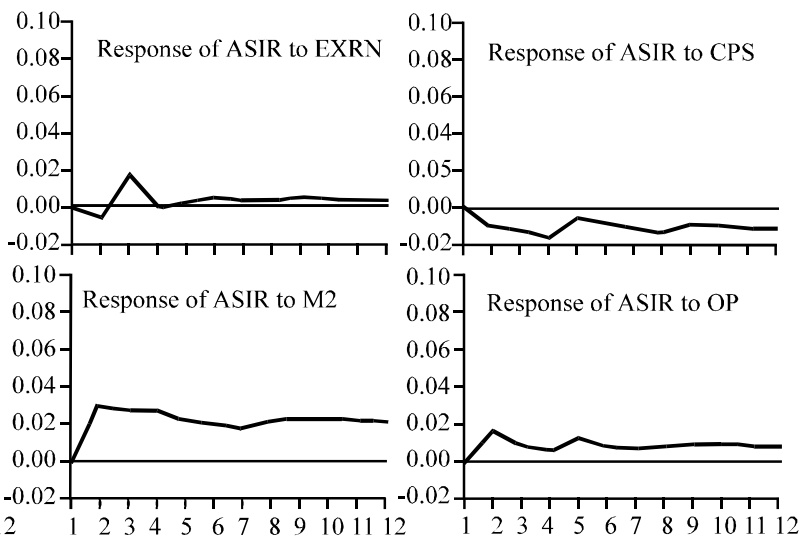

Fig. 4: Continue 


\section{J. Econ. Theroy, 6 (2): 48-60, 2012}

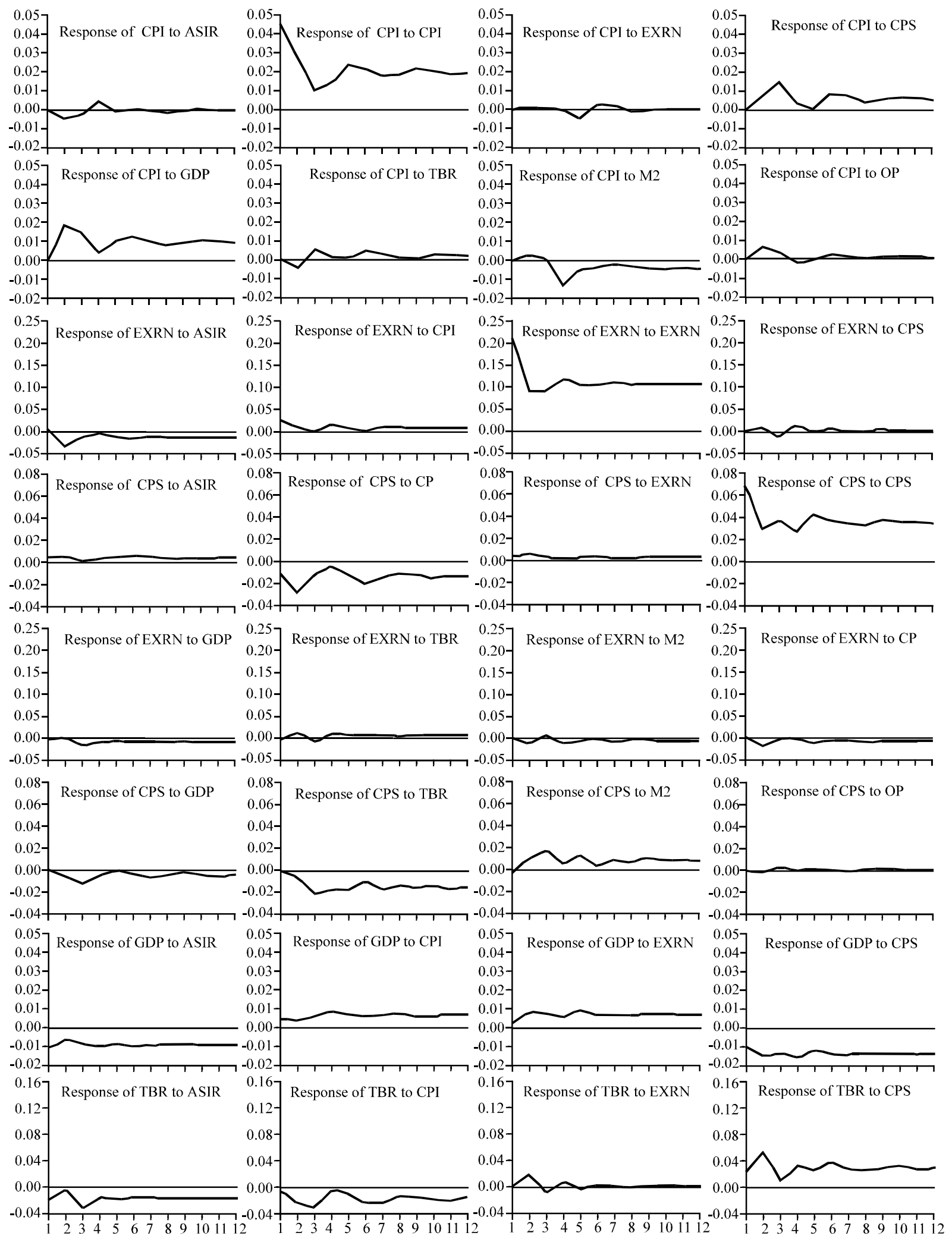

Fig. 4: Continue 
J. Econ. Theroy, 6 (2): 48-60, 2012

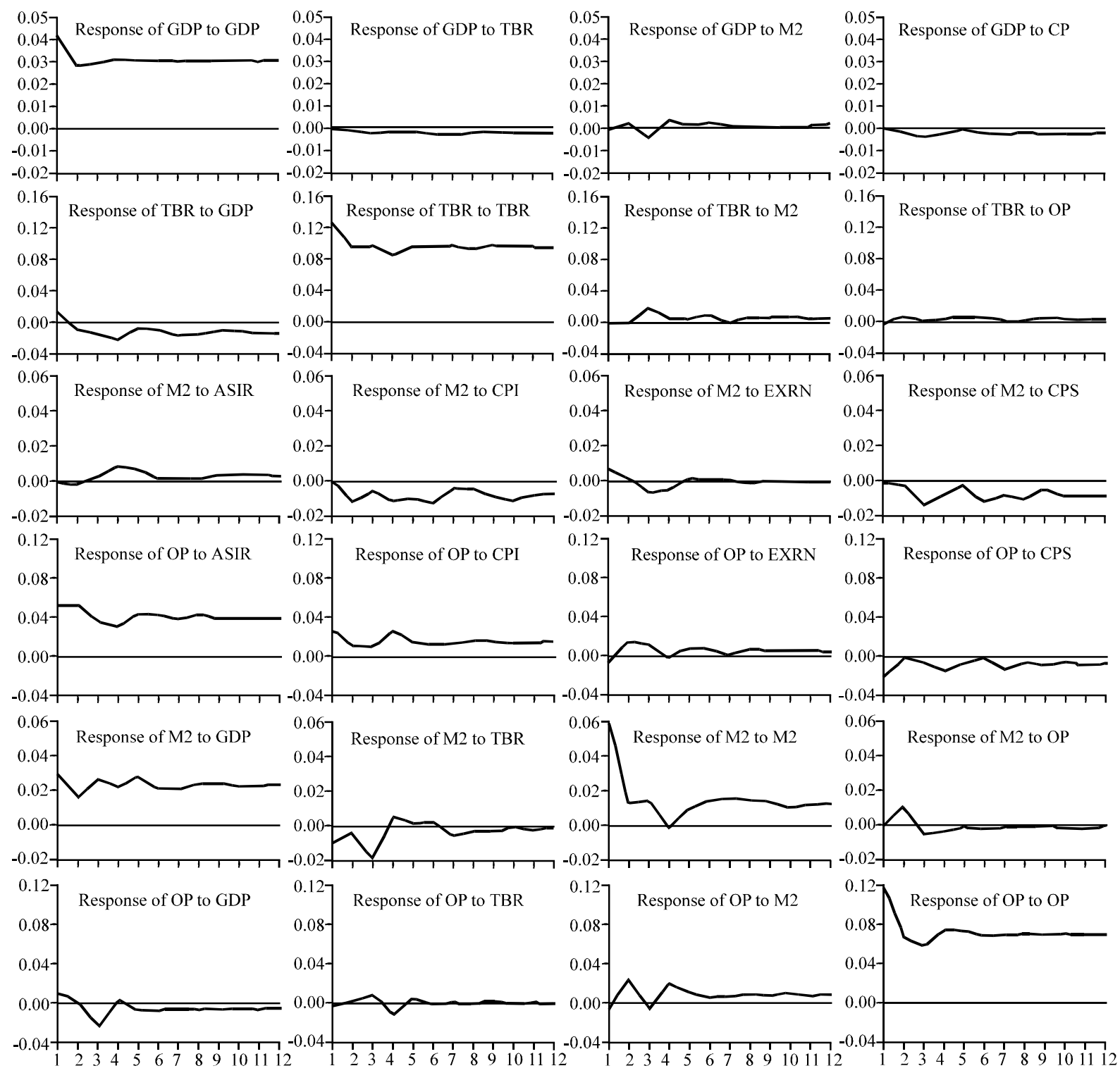

Fig. 4: Impulse response function of economic variables to the stock market

variables, the impulse response graphs show that ASIR respond significantly to the shocks of many economic variables in the system except that of exchange rate and gross domestic product. This means that a shock that causes exchange rate and gross domestic product to rise above their equilibrium level will generate no effect on the stock returns. Other economic variables generate significant effects on the stock return. Out of all the economic variables, a shock that causes broad money supply to rise above their equilibrium level will generate a stronger effect on the stock returns than similar shock on any other economic variables. This connotes that a standard deviation shock to the broad money supply introduces a stronger variable impact on the ASIR. The other economic variable that its shocks have effects on the stock returns are consumer price index, credit to the private sector, treasury bill rate and oil price. In other words, any shock to these variables also play significant role in explaining the stock returns in Nigeria, although their response to stock returns converges towards equilibrium overtime.

\section{CONCLUSION}

Economic distortions are important source of systematic risk and thus proxy for pervasive risk factors in the stock market. Therefore, it is found by the results that economic distortions are critical in influencing the 


\section{J. Econ. Theroy, 6 (2): 48-60, 2012}

performance of stock market and hence, the extent to which the market may be able to play its role in Nigeria. The study found out that there is a statistically significant long run relationship between economic distortions and the stock market performance in Nigeria.

\section{RECOMMENDATIONS}

Policy makers should therefore implement appropriate stock market enhancing policies that will not only promote stock market development but also ensure macroeconomic stability in the context of sustainable development. Implementation of appropriate economic policies is a primary requirement thatis expected to reduce risks of potential instability in the stock market as well as attract the growing pool of portfolio investment.

Reaching a modest competence in regulation and economic policy is crucial to effective attraction of foreign investors and thus financial integration. Integration can bring about improved liquidity, access to greater capital pools and efficient operations to the participating nations. Given the growing trend towards financial integration, Nigerian government must vigorously pursue policies that will enable them to benefit from global capital flows and avoid associated dangers. The combination of malfunctioning domestic finance, weak regulation and erratic economic policy is perfectly designed to get the worst out of financial openness. In countries where those failures are severe and cannot be corrected, an incautious opening of the economy to foreign capital is likely to do much more harm than good.

The existence of strong private sector with vibrant firms and general overhauling of corporate organizations are primary for stock market-economy linkages. Policymakers must attach priority to making corporations fit for public ownership. Building financial infrastructure is also germane for the stock market. Investors, both domestic and foreign are naturally hesitant about investing in countries where basic requirements such as roads, power, health services and utilities are inadequate. This is because these infrastructural facilities are germane for the development of productive firms, stock markets and economy as a whole. Therefore, any government that wants to improve on the performance of the stock market and also attract international portfolio investment must be clear about the importance of creating some basic preconditions for viable capital markets.

\section{REFERENCES}

Black, A., P. Fraser and N. Groenewold, 2001. US stock prices and macroeconomic fundamentals. Ph.D. Thesis, University of Aberdeen Working Paper.
Burmeister, E. and M. McElroy, 1988. Arbitrage pricing theory as a restricted non-linear multivariate regression model. J. Bus. Econ. Stat., 6: 29-42.

Chen, N.F., R. Roll and S.A. Ross, 1986. Economic forces and the stock market. J. Bus., 59: 383-403.

Clare, A.D. and S.H. Thomas, 1994. Macroeconomic factors, the APT and the UK stock-market. J. Bus. Finance Account., 21: 309-330.

Emenuga, C.A., 1994. Systematic factors and returns on equities in the Nigerian securities market. $\mathrm{PhD}$ Thesis, Department of Economics, University of Ibadan, Nigeria.

Emenuga, C.A., 1996. Macroeconomic Factors and Returns on Equities: Evidence from the Nigeria Capital Market. In: African Capital Markets: Contemporary Issues. Mensah, S. (Ed.)., Rector Press, Massachusetts, USA., pp: 86-96.

Enders, W., 1995. Applied Econometric Time Series. 1st Edn., Wiley, New York.

Fama, E.F. and W.G. Schwert, 1977. Asset returns and Inflation. J. Financial Econ., 5: 115-146.

Flannery, M.J. and A.A. Protopapadakis, 2002. Macroeconomic factors do influence aggregate stock returns. Rev. Financial Stu., 15: 751-782.

Gertler, M., 1988. Financial structure and aggregate economic activity: An overview. J. Money Credit Bank., 20: 559-588.

Green, C.J., P. Maggioni and V. Murinde, 2000. Regulatory lessons for emerging stock markets from a century of evidence on transactions costs and share price volatility in the London Stock exchange. J. Banking Finance, 24: 577-601.

Jefferis, K., C. Okeahalam and T. Matome, 2001. International stock market linkages in South Africa. AERC Research Paper 105. Nairobi, Kenya.

Johansen, S. and K. Juselius, 1990. Maximum likelihood estimation and inference on cointegration with application to the demand for money. Oxf. Bull. Econ. Stat., 52: 169-210.

Johansen, S., 1991. Estimation and hypothesis testing of cointegration vectors in gaussian vector autoregressive models. Econometrica, 59: 1551-1580.

Kandir, S.Y., 2008. Macroeconomic variables, Firm Characteristics and stock returns, Evidence from Turkey. Int. Res. J. Fin. Econ. Theory, 13: 36-45.

Maysami, R.C. and T.K. Koh, 2000. A vector error correction model of the Singapore stock market. Int. Rev. Econ. Finance, 9: 79-96.

Mukherjee, T.K. and A. Naka, 1995. Dynamic relations between Macroeconomic Variables and the Japanese Stock Market: An application of a vector error correction model. J. Financial Res., 18: 223-237. 
Osei, K.A., 2002. Asset pricing and information efficiency of the ghana stock market. AERC Research Paper, http://www. amazon. com/pricing-informationefficiency-market-research/dp/9966944656.

Poon, S. and S.J. Taylor, 1991. Macroeconomic factors and the UK stock-market. J. Bus. Finance Account, 18: 619-636.

Rahman, A.A., N.Z.M. Sidek and F.H. Tafri, 2009. Macroeconomic determinants of Malaysian stock market. Afr. J. Bus. Manage., 3: 95-106.

Roll, R. and S.A. Ross, 1980. An empirical investigation of the arbitrage pricing theory. J. Finance, 35: 1073-1103.
Ross, S.A., 1976. The arbitrage theory of capital asset pricing. J. Econ. Theory, 13: 341-360.

Soyode, A., 1993. Structural adjustment programme and its impact on the Nigerian Stock market. Res. Third World Account., 2: 335-352.

Tobin, J., 1969. A general equilibrium approach to monetary theory. J. Money Credit Banking, 1: 15-29.

Tsuyoshi, O., 1997. Determinants of stock prices: The case of Zimbabwe. IMF Working Paper, http:/www.imf.org/external/pubs/ft/wp/wp97117.pdf. 